\title{
10
}

\section{The Concept of the Absolute and the}

Dialectical Method

My former lecture was devoted to a general study of the transition from Kant's view of the self to that deeper but more problematic conception of the self which characterized the later idealism. Before characterizing further that conception, let me first remind you of some of the external conditions under which the German philosophical thinking of the time now in question took place.

\section{I}

Kant published his Critique of Pure Reason in $187 \mathrm{I}$. The next ten years were marked by the first reception of that book in Germany, by the earliest efforts to understand, to expound, to criticize, and to supplement Kant's doctrines, and also by the appearance of the most important of Kant's own further expositions of his principal philosophical teaching. In $179^{2}$ the literary career of Fichte began; and in 1794 that philosopher published the first statement of his own form of idealism, in his Wissenschaftslebre. Almost at the same moment the young Schelling set out upon his career of rapid,

[Reprinted from Lectures in Modern Idealism (New Haven: Yale University Press, 1919), pp. 63-86, by permission of the publisher. (C) 1919, by Yale University Press.] 
brilliant, and changeful expressions of doctrine. In the last year of the century, Hegel's professional career as a teacher of philosophy began, when he went as Privat-Docent to Jena; and his own characteristic teachings received their first extended formulation in his Phaenomenologie des Geistes, published in 1807 . All these works were, at the moment, but single examples of a very large philosophical literature which Germany was producing in those years.

We are here concerned with the beginnings of idealism. It requires only a moment's reflection upon the great historical events that were contemporary with this remarkable outburst of philosophical activity, to remind us what manner of time that was. In a general sketch of the philosophical situation of those years, I have indicated, in my Spirit of Modern Philosophy, some of the relations of the philosophical to the literary movement of that period in Germany, and I have also endeavored in that book to characterize some of the personalities who were concerned in both movements. It is not my purpose to repeat here in any detail these more popular aspects of the early history of idealism. But I do not wish you to lose sight of the fact that the abstract thinking whose fortunes we are trying to portray, was inevitably, and quite normally a reflection of the tendencies and of the problems of the civilization of just that age. I beg you to keep this fact in mind as you follow these lectures, whenever the problems and the theories of the philosophers seems to you, for the moment, hopelessly remote and unreal. Philosophy and life were then in far closer touch than, as I fear, they are today in the minds of many people. All this technical speech of categories and of knowledge, of phenomena and of the self, of the individual and of the Absolute-all this speech, I say, was rendered vital to the philosophically disposed readers of that time by the fact that, to their minds, it bore upon the very life problems which the Revolution and the new social ideals and the passions of the romantic movement made so prominent.

Kant's first Critique had won so wide a public hearing in Germany, in the eighties of the eighteenth century, largely because of the emphasis which its happily chosen title put upon the interests of the human reason. The word reason was to the age that immediately antedated the French Revolution very much what the word evolution has been to our own generation-a sort of general comforter of all those who felt puzzled and longed for light. What- 
ever the issue, the enlightened souls of that time said, "Reason will set us right." Reason was to be the all-powerful substitute for religion, tradition, superstition, authority, custom, prejudice, oppression, in brief for whatever man happened to view as a galling harness. Reason was to be a chain breaker, jail deliverer, world reformer. Thus, when Kant undertook in his Critique an exhaustive survey of the province, the powers, and the limits of the reason, he had in his favor not merely technical but also deep-seated popular interests. So he won a well-deserved attention.

The results of Kant's Critique seemed to many disappointingly negative. But then, that was an age of great destructions. When the Revolution came, many institutions which had long seemed to be things in themselves, showed that they were nothing but phenomena. And when new constitutions and new social orders had to be planned, the spirit of the age emphasized the fact that, at least in the social world, it is the office of the human intelligence to impose its own forms upon the phenomena, and to accept no authority but that of the rational self. So in that day the spirit of the Kantian philosophy reflected, in a very practical sense, the tendencies of the age. The destructive as well as the constructive features of this new philosophy were in harmony with that reforming spirit in consequence of which the word reason at length became, as the Revolutionary ideals matured, not a mere name, but a term for a great regulative force, whose value lay no longer in its vaguely abstract authority but in its creative power, in its capacity to mould plastic phenomena into conformity with its forms.

The transition from Kant's philosophy to the later idealism was again a reflection of the spirit which determined the course of contemporary social events. Three features marked the mental life in Germany during the decades with which the eighteenth century closed and the nineteenth century opened, say from 1770 to 1805 . The first feature was the great development of actual productive power in scholarship, in literature, in imaginative work generally, and the accompanying increase in the popular respect for great individuals. This tendency is visible from 1770 until the close of the old century. The second feature was that deepening of sentiment, that enrichment of emotional life, which characterized first the storm and stress period, and later both the classical and the romantic literatures of Germany in those decades. The third feature was that relative indifference to mere political fortunes, that spirit of 
world-citizenship, that fondness for what Jean Paul called "the empire of the air," which by the close of the old century became so characteristic of the most representative Germans at the very time when, as the Napoleonic period began, the national unity and even the political existence of Germany seemed to be hopelessly lost. These three features of German mental life had a close connection with the great social movements of that period. The spirit of the revolutionary age, even before 1789 , had set free the great individuals. The intense social activities of Europe after the political revolution began, found their expression, in Germany, not indeed for the time in effective political reconstructions, but rather in the form of a vast increase both of scholarly and of imaginatively creative mental life. Meanwhile this age of great experiences not unnaturally became also an age of great romantic emotions, in which Germany, by virtue of the temperament of her people, led the way. And at a period when political and military successes proved to be impossible for the divided Germany as it then was, the representative leaders of German public opinion preserved their spiritual independence, protected their individuality by deliberately ignoring, or else by defying political fortunes, in brief by aiming to show their moral superiority to the external mishaps of their country. This was the age and the land for a somewhat unpractical and fantastical idealism. It was also the land and the age for really great thoughts, whose influence in later times and in other forms will be permanent.

Two topics were thus rendered especially prominent in the minds of representative German thinkers, whether they were technical philosophers or not. The first was the self, not merely what we now call the empirical ego of psychology, but the significant self, the hero of the storm and stress literature of the seventies and eighties, and of the romantic emotions of later literary art, the sovereign of the new spiritual order-the self that could rise above fortune and win without external aid. The second was what one may call, in a well-known sense, the invisible world in which the self is immersed-the realm into which Goethe's Faust seeks to penetrate at the outset of the poem-the region, namely, of ideal truths, of truths which you do not so much discover through observing either physical or political facts, as by investigating moral and aesthetic truth, and by consulting what you may at first imagine to be magic powers. 
So far as the self was prominent in the minds of the Germans of that time, the tendencies of the age were towards a somewhat romantic type of individualism. Goethe's Faust in its earliest form, Schiller's early dramas, Goethe's Prometheus, Friederich Schlegel's romantic irony, Fichte's popular work called the Vocation of Man -these are representative expressions of the various sorts of individualism to which this period sooner or later gave birth. Such individualism was seldom of the type which Nietzsche has in our own days emphasized. The well-known doctrine of Nietzsche is that of an individual equally merciless to himself and to others. It is a restlessly intolerant and muscular individualism which despises its own sufferings, an idealism without any ideal world of truth, a religion without a faith, a martyrdom without prospect of a paradise. But this individualism of the storm and stress, of the classical and of the romantic periods of German literature was always, in the first instance, an emotional rather than what one might call a motor individualism; and it had great faith in its own discoveries of ideal truths. Its excesses were much more sentimental than are those of Nietzsche, and it usually had a religious faith, unorthodox but glowing. It might be rebellious; it might even undertake, in ideal forms, world-destroying revolutionary enterprises. But it never really despised its own affairs of the heart, as Nietzsche proudly despises his own emotional illusions. On the contrary, the individualism of that time always sought great heart experiences, and generally believed in them, whereas, in our day, individualism loves to assume a more drastic and contemptuous tone, where the interests of the heart are concerned. When German individualism, in those romantic old days, was philosophical and reflective, it might be highly critical; but it was withal, in the end, either fantastically or even laboriously constructive, rather than mainly iconoclastic, whereas our extreme individualists are fond of making, as it were, pyramids of the skulls of their enemies. Individualism is indeed always strongly negative, but the individualism of that time had its hearty positive enthusiasms, and often hugged its very illusions. It destroyed, but it was fond also of building its own temples, which were often indeed rather too much in the air.

As for the other topic of that time, the ideal world, that of course has often attracted the eager interest of the cultivated minds of mankind. The ideal world for the German thinkers of those 
days differed from that of Plato, as well as from that of mediæval tradition. This new realm of the ideal was first of all a region where great ethical interests were prominent, but these interests had modern forms, determined by the social struggles of the age. Freedom, the ideal social order of modern society, the ideals of beauty suggested by the newer romantic poetry-these were among the notable problems of this time. So far as one went beyond the individual, the mysterious linkage of the self to other selves and to the whole universe of being, formed the central problem of philosophy. The religious views of the time meanwhile became altered; and instead of the God of traditional theology, and also instead of the world-contriving and utilitarian divine being of the earlier eighteenth century deism, one now sought for the Absolute-a being characterized in that time by two principal attributes: first, that the Absolute was impersonal and thus relatively pantheistic in type; while, secondly, the self was nevertheless the best image and revelation, the true incarnation, of this Absolute. This paradox, that the self was the center of the universe, while the Absolute was nevertheless impersonal, formed the crucial issue of the time.

II

I am thus led from this general sketch of the state of German mental life in the years in question, back to the properly philosophical field.

The early idealists, then, made the problems of philosophy center about two principal conceptions, that of the self and that of the Absolute. We have seen how these thinkers, in so far as they were guided by their technical interests, came by the first of these problems. The Kantian deduction of the categories had given this problem of the self its new form, and had done so by emphasizing the fact that all phenomena (and phenomena, alone, according to Kant, are knowable) are inevitably moulded in their form by the conditions which are imposed upon them by the self in order that they may become known to this self. As soon, however, as thinkers had undertaken to look closer into Kant's problem, to see why the self has these categories, and no others, and to understand how the self imposes these categories upon the data of sense, it had become obvious that Kant's account of the matter was incomplete. 
The self remained even for Kant a problem. Kant's own emphasis, in his later writings, upon the ethical aspects of the self, still further made it necessary to understand where the basis and the true unity of self-consciousness lies. And when the philosophers further attacked this problem of the self, their interest was intensified by the whole spirit of an age which, as we have now seen, believed in the self, believed in individuality, gloried in the inner life.

We have now also seen why the other problem-the problem of the Absolute-was almost equally emphasized by the interests of that day. Whatever the true self is, its nature is hidden, at least from our ordinary knowledge, in the depths of unconsciousness. Only when we learn to reflect can we hope to penetrate any of its deeper mysteries. But when we reflect, we at once bring to light a new question, the question of the relations between the practical and the theoretical life of the self. The two expressions of selfconsciousness, "I know," and "I do," stand, in Kant's account, in a profoundly baffling relation. The unity can here be found only through some principle which Kant left still undiscovered. Closely connected with this problem is another which Kant indeed touches but only to leave it for his successors to develop. This problem is furnished by the relations amongst the many selves. That they possess a common nature, is implied in every step of Kant's discussion of the human intellect. How this common nature is to be further defined, this matter Kant treats with a careful reticence. What indications he gives are paradoxically baffling. Kant's ideal moral world of rational agents-the object of what he defines as our well-warranted faith-is a realm of ethical autonomy, a kingdom of free selves, a distinctly pluralistic community, as Professor Howison has, with historical accuracy, insisted. The virtual self of the deduction of the categories, however, is a principle whose unity determines the mutual relations of all possible human experiences, and whose universality defines the sense in which empirical judgments are valid for all men. If you give to this principle any further definition than Kant had given it, the unity of this true ego invites a monistic formulation. Kant has no reason to decide between such a monism and his ethical pluralism. The one is a concept of his theory of knowledge, the other of his ethics. And ultimate truth we cannot know. His judgment in these matters is theoretically suspended. But for his idealistic successors such deliberate suspension of judgment proved impossible. We thus begin to see why, in 
view of the conflict between the unity of the world of truth and the pluralism of the world of action, these idealists were led to seek a solution in terms of the conception of an impersonal Absolute, which is nevertheless the ground and the source of personality.

It would of course be inaccurate to ascribe to the concept of the Absolute as these men formed it the sole office of accounting for the relations of various selves. Unquestionably the magnitude of the social movements of those times, the vast changes of civilization that were then under way, the elemental passions that were then set free, the sense of an overwhelming fate, predetermining human affairs-all these things influenced the philosophers in their conception of the Absolute. In sharp contrast to the individualism of the revolutionary period, stood the fact of the blind power of the mob, which the Revolution had for a while so impressively demonstrated. The general awakening of the peoples, viewed as great masses, was as notable a fact of the age as was the importance of the heroes of the day. Napoleon, when he came, seemed to his admirers less a mere individual than the incarnation of some demonic spirit of a whole nation's life. The hackneyed story relates how Hegel, who one day saw Napoleon for a moment after the battle of Jena, said that he had met the Weltgeist zu Pferde. In those days, one could not long remain merely individualistic. The self was prominent; but the universe was impressing upon the beholder, in a new way, its possession of vast impersonal forces which used individuals as their mere tools. In the light of such experiences men began to read the philosophy of history in a new way.

Nevertheless, something more than the social and historical problems impelled thinkers towards an interpretation of the world in terms of an Absolute. Kant's theory was, within its carefully guarded limits, a doctrine regarding the bases of our empirical knowledge of phenomena. It was no theory of nature. Our understanding determines forms; it cannot predetermine the material that shall fill these forms. Hence nature remains to us a mystery. We can never deduce a single concrete fact. Why, for instance, organisms exist in nature with the appearance of having been designed, we can never hope to fathom through our understanding. Kant once more resolutely suspends his judgments. We can understand the order of phenomena; we can never pierce to the heart of things and find why they exist.

The idealists could not accept this Kantian limitation. Once 
they had disposed of Kant's shadowy and unknowable things in themselves, the problem of the world became for them, as we have seen, one about the true nature of the self. This problem, however, sent them far beneath the threshold of our ordinary consciousness. Whatever it is that determines the experience of the self, must also determine not only all of the forms and the relations of the many selves but also the true basis of all the phenomena that appear to us as physical nature. Grant that the physical world is a phenomenon, our phenomenon. Then it is our own deeper nature which determines this phenomenon to appear thus foreign to us, and ourselves to seem as if we were mere products of its mechanism. All experience is appearance for the self. Well then, we must be able, if we reflect rightly, to discover, not indeed the reason for every detail of the world, but at least the general reasons why our experience presents to us here the organic and there the inorganic type of phenomena, here the growth of things, and there their decay. We must be able to learn why it is, and in what sense, that the individual man appears and must appear to us as a phenomenon amongst phenomena, as a product of nature-in brief, why man, who bears about in his own inmost core the very secret of the universe of phenomena, still seems, and has to seem, as if he were the mere creature of a day, whom a mere wound can destroy, whom a pestilence can slay. In sum then, this philosophy must undertake to be a philosophy of nature, and to discuss, not merely the forms of things, but their presentation, source, and meaning.

I suggest thus in outline certain of the main thoughts of this philosophical movement, attempting at this point neither criticism nor defense of these thoughts. They were at least a natural product of the situation. And one sees why a philosophy which was equally to explain our own inner as well as the basis of our experience of outer nature, was readily disposed to attempt to unify its notions by means of an impersonal conception of the Absolute, a conception still to be kept in the closest touch with the conception of the true meaning of the self.

In addition to the problems of the self, of the many selves, and of nature, the philosophy of this time was deeply moved by the new form which the problems of religion had inevitably received in consequence of the spirit of the age. Individualism had broken with theological authority. The eighteenth century worship of reason had long since rendered rationalism in theology a favorite 
philosophical ideal. The Kantian philosophy, in relegating religion to the position of an indemonstrable ideal, to be purified into a simply rational faith in God, freedom, and immortality, had only the more set free the tendency to reconstruct the contents of tradition in accordance with the spirit of the time. The new conception of the Absolute was thus inevitably developed under the influence of a predisposition in favor of a new theology. There is a profoundly religious motive which, both in Hindoo and in Western thought, has for thousands of years underlain the view that one comes into closest touch with the Divine, not without but within one's own true self. The Hindoo seers and the Christian mystics had agreed in seeking an unity of the self and of the Divine wherein the nature of each is intimately revealed at the moment when they are nearest together. The new idealism revived these ancient thoughts but gave them its own form. What is at the heart, at the root, at the ground of the self, must be, in terms of the philosophy of which Kant's doctrine had given such novel forms, the Absolute, the common root and ground of all selfhood, and of all nature. This then, so these thinkers hold, will be what the ancient faith has meant by the name "God." Only the new philosophy will be no merely mystical experience. It will be a well-wrought and systematic doctrine, with a method of its own. A revised and completed deduction of the categories shall render the new formulation of religious faith compatible with reason. The triumph of the new age shall thus be the union of the "form" of a new rationalism with the "matter" of ancient mysticism. Such, I say, is in general the ideal of the religious philosophy to which this time gave birth.

\section{III}

You have now before you a few of the fundamental ideas of the philosophy of this period. We must next suggest something regarding the method of thinking which became characteristic of this philosophy. Concerning this method a great deal of misunderstanding exists amongst those who are not acquainted with the matter at first hand. These Germans, one says, attempted to evolve all things out of their inner consciousness. So much, and no more, does one, only too frequently, know about what went on in the procedure of the early idealistic metaphysicians. Those who thus 
sum up the whole matter are accustomed to conceive our idealists merely as imaginative persons who fancied whatever they pleased, and who then hid from themselves and their pupils the arbitrariness of their opinions by means of much unintelligible phraseology. The one amongst the greater early idealists who gave most ground for such an opinion was Schelling, a genius, but in his youth an unprincipled and voluble genius, who began to write with enormous rapidity when he was twenty, and who had reached the culmination of his most productive period, and of his influence, before he had well passed thirty years of age. No doubt Schelling at his worst is indeed an arbitrarily imaginative person; his early won fame intoxicated him, he lacked due self-criticism, and he did not take the trouble properly to digest his large store of information concerning the current physical science of his day, while he nevertheless attempted to use this information for the purpose of constructing a new Philosophy of Nature. The result is that he wrote much upon this topic which remains both fruitless and unreadable. Yet even in the course of such hasty work, Schelling often showed a fine instinct for essentially important leading ideas such as the science of his day was beginning to develop. Some few of his own leading ideas in regard to nature are of decidedly more importance than the first glance indicates. ${ }^{1}$

However, it is no part of my task at this moment to discriminate at all exhaustively between the good and the bad in the methods of thinking used here or there by Schelling or by any other of the thinkers of the time. What is here needed is a broad outline of the most novel, most characteristic, and least arbitrary of the methods which these philosophers gradually developed. This was the so-called dialectical or antithetical method. It meant much more than any purely arbitrary use of the constructive imagination. It did not consist of anything that can be fairly described as an evolving of the facts out of one's inner consciousness, in so far as that phrase suggests mere fancifulness. This method, on the contrary, had a certain very marked exactness of its own. Used within due limits it will always remain a valuable instrument of philosophical thought. Let me try to indicate at this point the nature of this dialectical method.

${ }^{1}$ Cf. the author's "Relations between Philosophy and Science in the First Half of the Nineteenth Century." Science, N. S., XXXVIII, 1913, pp. $5^{67-}$ 584.-ED. 
Historically speaking, this method is derived from Socrates, and elaborated in the Platonic dialogues, especially in the Parmenides, and to some extent in the Sophist, in the Phedo, in the Theretetus, in the Phedrus and elsewhere. As Plato used it, it often consists in developing and then comparing antithetical, i.e., mutually contradictory, doctrines, partly for the sake of leading the way, through natural, or perhaps inevitable, preliminary errors, to some truth which lies beyond them, and partly for the sake of exhibiting a complex truth in its various aspects, by looking at it first from one side and then from another in order finally to win a combined view of the whole. Thus, in the Thecetetus, the Socrates of the dialogue aims towards the goal of a sound definition of knowledgea goal which is indeed not reached in the dialogue-by first setting aside, through an elaborate dialectical process, the natural preliminary error of defining knowledge as sense impression. In the introduction to the Republic, false views of the nature of justice are expounded in order to clear the way for the true definition. On the other hand, in the Phredrus two views of nature and the effects of love are set in antithesis in order even thereby to depict the truth which justifies both views. This truth is that there is a conflict in the human soul of the two natures, the lower and the higher, and that hereby our mortal lives and our future destinies are determined. Love is a soul-destroying madness. Love is also a god-like passion, a divine madness, whereby we learn our true destiny. The conflict between these two theses is depicted, in this dialogue, as simply the abstract expression of the moral conflict of life, the warfare of the spirit with the flesh.

In addition to such more formal opposition of thesis and antithesis, the dialectical process plays, in Socratic dialogues, the general part of moving principle of the whole discussion. Through a constant self-analysis of its own defects, our thinking is led to what often appears in the dialogues to be its only possible mode of self-expression. Without erring, and transcending our error, we, as sometimes suggested by the Socratic irony, simply cannot become wise. Such is human wisdom; namely the self-consciousness that observes one's own forms of unwisdom. Without such self-consciousness, one remains blind in one's own conceit. Yet to get it, one must err and then rise above the error.

The thought thus somewhat dimly indicated by various Socratic expressions in the Platonic dialogues-the thought that error is not 
a mere accident of an untrained intellect, but a necessary stage or feature or moment of the expression of the truth as it is in itselfthis thought is the very one which the idealists of our period not merely admit, but consciously emphasize, and develop in new forms. Without the Platonic dialogues this dialectical method would indeed never have existed. But one cannot say that our idealists merely took over the old method and applied it to new problems. On the contrary, in the end they so revised it as to lead them to the thesis that philosophical truth is, as they gradually came to say, essentially dialectical, i.e., you cannot express the highest insights except in the form of a series of antitheses. Although, as I have suggested, the Platonic dialogues contain indications of such a tendency, Plato's own conception of ultimate truth tends to make the dialectical process appear rather an incident of our human life than a necessity of the truth as it exists in the pure realm of the Ideas themselves. Such evidences as Plato emphasizes for the thesis that the Ideas themselves are the result of a dialectical process, remain undeveloped. These idealists, however, devote a great deal of space to making the dialectical aspect of truth very explicit.

The new form of the dialectical method was also due, in part, to Kant's famous doctrine of the antinomies. Kant undertook to show that the human reason becomes involved in conflicts whenever it attempts to discuss the beginning of the world in time, the limits of the world in space, the ultimate divisibility or non-divisibility of matter, the possibilty of the free initiation of a series of causes and effects, or the existence of a necessary being. Thus one can demonstrate, with equal cogency, that if the real world is in time at all, it must have had a beginning, yet cannot have had a beginning. If the real world is in space, it must be limited, and with equal cogency can be proved to be unlimited; and so on. Kant states these antinomies and the argument for both theses and antitheses and then shows that the solution depends upon distinguishing between the world of things in themselves and the world of phenomena. Kant's solution need not here further concern us. We know that it could not content our idealists, who did not admit the validity of the Kantian distinction here in question. But the fact that Kant declared the appearance of these antitheses to be essential to the very life of the human reason, so that the reason, according to him, always expresses itself in these antithetical de- 
mands upon our conceptual powers, was of more importance for the idealists. For them the question consequently tends to take this form: Whatever the solution of any antinomy, why do such antinomies, real or apparent, arise in our minds at all? Why do we not come at the truth directly, or else, if ignorance besets us, why do we not become directly, or through our mere failures to get light, conscious of our ignorance? Why are there regions of our thinking where conflicting judgments appear to us to possess an equally cogent evidence, so that it is to us as if both a thesis and an antithesis were positively true?

No one could be interested in such a question unless he had cases of apparently dialectical or antithetical thinking prominently before his mind, and unless such instances seemed to him no results of merely accidental or easily avoidable blunders. The idealists actually believed themselves to be in possession of such notable cases. Moreover they came to regard such cases as characteristic of philosophical thought, and, in fact, of philosophical truth. Still holding ourselves free from any prejudgment of the merits of this view of philosophical truth, let us now endeavor merely to illustrate some of the forms of the dialectical method.

For the first class of illustrations one may again turn to the problems which the spirit of that time furnished to the idealists. Whatever else the age of the Revolution and the following Napoleonic period were, they were such as to suggest that the dialectical, the antithetical, the contradictory occurrences in our thinking are founded on tendencies very deep in human nature. It was not the mere blundering of the individual men of those days which led to rapid and contradictory changes of popular opinion and of social action; for instance, the practical expression of the abstract doctrine of the rights of men led to a social situation in which the rights of the victims of the Terror were so ruthlessly sacrificed; the propaganda of universal human freedom was sustained by bloody wars; and in the end, the outcome of the Revolution was a military despotism. It is hardly a very deep account of these processes to say simply that the pendulum swings, and that excessive action leads to reaction. This is true. But it is a deeper truth that the ideas and passions of such a time are in their nature an union of antithetical tendencies. The passion for human liberty, in the form which it took during the early French Revolution was obviously an example of what Nietzsche has called the Wille zur 
Macht. Whatever the causes of the French Revolution, when it came it awakened a love of human freedom which was also a love of human might. The two aspects of this great fondness were antithetical, and for the moment inseparable. As the process developed they contended, and the one contradicted the other. How could one express one's regard for human freedom except through one's might? But might can be expressed only through finding some one to conquer. Conquest depends upon discipline; discipline requires a ruler.

Of course this obvious instance of the revolutionary tendencies awakened the reflections of our philosophers. But the instance did not stand alone. All the greater emotions are dialectical. The tragedies of the storm and stress period, and of the classical and romantic literature, are portrayals of this contradictory logic of passion. Faust asks the highest, and therefore contracts with the devil and destroys Margaret. The romantic poets so loved emotion that their works are mainly devoted to depicting the vanity of all the emotions. Outside of German literature, and in later times, one finds numerous instances of similar literary expressions of the dialectics of the emotions. The fascination and the power of Byron are due to his contradictions. Because of the loftiness of his emotional demands upon life, he finds only triviality and failure. His most characteristic ideal remains such a being as Manfred, whom the demons respect solely because his sins are deeper than theirs and because his internal remorse makes the external penalties of their hell seem by comparison insignificant. Manfred's poetic dignity consists in his absolute consciousness of his own moral worthlessness in all matters except his honest self-condemnation. Others are deluded into hope or fear. He knows that there is nothing to lose; and this makes him a hero. Instances of the dialectics of the emotions abound in the European literature of the period between 1770 and 1830. And not all such instances are tragic. There is a glory in winning all by abandoning all. Wilhelm Meister, like Saul, sets out to seek asses, and finds a kingdom. Or, as the classic lyric puts the cheerful aspect of this same dialectic:

Ich hab' mein' Sach' auf Nichts gestellt Und mein gehört die ganze Welt.

It is easy to say that all such phenomena express precisely the unreasonableness of the emotions. But a closer view shows that 
this dialectical tendency belongs rather to the active will than to the mere emotions. Upon this both Hegel and his bitter enemy Schopenhauer, though in very different ways, are agreed, and upon this they both insist. The mere sentimentalists amongst the romantic poets express such crises and such changes of point of view less effectively than do the more active natures. Byron is by nature a man of action who fails to find an absorbing career until he writes his last lyric after landing in Greece. That is why his utmost cynicism or his profoundest gloom has always a note of manliness about it that holds one's attention. To turn in the other direction, Goethe, full of emotional experience as he was, is rather a restlessly active man than a man of mere feeling. The dialectical process of his own activity brought him indeed to that splendid consciousness of calm and of inner self-possession which marked his best years; but his processes are always those not of the man of merely changing sentiments but rather of the man who became the controller of his fortunes, the master of his deeds.

Development through contradictions belongs then to the will, using that word in its merely popular sense, rather than to the relatively passive emotions. Can one still say that all such processes, whether of the emotions or of the will, belong ipso facto to the relatively irrational side of life? I will not at this moment answer this question upon its merits. It is enough for my present purpose to say that the idealists, whose position I am here merely illustrating, insist that this is not the case. They insist that the law of development through antitheses is characteristic not merely of the feelings, nor yet merely of what is unreasonable about our feelings and our will, but of the very life of reason itself. I have used the foregoing illustrations in order to show how deeply seated the dialectical or antithetical tendencies were in the life and in the literature of that age. The philosophy of our idealists was a reflection of the spirit of that time. Whether rightly or wrongly, these idealists did not seek to philosophize by merely purging their thoughts of all such antithetical tendencies, or by demonstrating that a sound thinker defines just one solid and stable truth such as enables you to ignore, once for all, every contradiction as a mere blunder. On the contrary, they developed a method which depends upon recognizing that the truth is a synthesis of antithetical moments or aspects, which does not ignore but unifies opposition.

This notion of truth is to many people so unsympathetic that 
I can only hope, at the moment, to indicate some way in which one who approaches it for the first time may be aided in treating fairly a point of view which only our later illustrations can render even tolerably articulate. One is tempted to say, "Fickle emotions we know, contradictory attitudes of will we know, but the hypothesis of an essentially antithetical constitution of rational truth is a self-confessed absurdity. Something must be true. What is true excludes what is not true. Antithesis may arise, through our ignorance and our hastiness, on the way towards truth. Conflicting hypotheses may even wisely be formed, weighed, tested, as a means to the discovery of truth. But an antithetical or dialectical constitution of the truth is logically impossible."

I will not here undertake to answer this objection. I am only trying to smooth the way towards an historical appreciation of this idealistic movement; so I may as well point out a motive which may help to make the dialectical method comprehensible to students of contemporary philosophy. Our idealists were, one and all, in a very genuine sense what people now call pragmatists. They were also, to be sure, absolutists; and nowadays absolutism is supposed to be peculiarly abhorrent to pragmatists. But of the historical, and perhaps also of the logical relations of pragmatism to absolutism we shall see more hereafter. What I now emphasize is that all these thinkers make much of the relation of truth to action, to practice, to the will. Nothing is true, for them, unless therein the sense, the purpose, the meaning of some active process is carried out, expressed, accomplished. Truth is not for these postKantian idealists something dead and settled apart from action. It is a construction, a process, an activity, a creation, an attainment. Im Anfang war die That. It is true, as I have said, that on the religious side these idealists had a certain sympathy with the tradition of the mystics whose God was found through an interior illumination. But I also said that the new doctrine was never meant to be any mere revival of mysticism. I tried to suggest its spirit by calling its religion a synthesis of mystical and of rationalistic motives. What I now add is that these rationalistic motives were dialectical, largely because of the stress that these thinkers laid upon the active element in thought, in truth, and in reality.

The connection between what I have called the pragmatism of these thinkers and their dialectical method was the same as the connection already indicated, in our illustrations of the general 
tendencies of the time, when we pointed out how the life of the will itself involves the presence of antitheses and of conflicting motives. If truth is what some active process finds, but finds only because this very activity itself creates the truth, then truth will not be something that you can merely describe in terms of monotonous consistency but will partake of the conflicting motives upon which the will depends. This thought lies very deep in the whole philosophy of this age. How this thought is expressed, our later illustrations will show. 
Part IV

Religious Questions 
